\title{
Reduction of deoxynivalenol and nivalenol content during roasting of naturally contaminated barley
}

\author{
Blanca E. Yumbe-Guevara and Takumi Yoshizawa \\ Department of Biochemistry and Food Science, Faculty of Agriculture, Kagawa University \\ (M iki, Kagawa 761-0795, Japan)
}

\begin{abstract}
Summary
Decomposition of deoxynivalenol (DON) and nivalenol (NIV) during roasting of naturally contaminated barley was determined by GC-MS, and by ELISA using a monoclonal antibody which recognizes the partially acetylated derivatives of DON and NIV (3,15-diacetyl-DON and 3,4,15-triacetyl-NIV). As determined by GC-MS, DON and NIV were decomposed with the extent of reduction dependent upon temperature and processing time. By ELISA, a clear decrease in the toxin level was observed above $170{ }^{\circ} \mathrm{C}$, whereas at $150{ }^{\circ} \mathrm{C}$ the toxin level increased after 5 and 30 min heating in spite of a slight decomposition observed by GC-MS. This phenomenon was also confirmed when the standard toxins were heated at $150{ }^{\circ} \mathrm{C}$, indicating that heat-induced derivatives of the toxins may have a stronger cross-reactivity against the antibody.
\end{abstract}

Key words : deoxynivalenol, nivalenol, roasting, GC-M S, ELISA

(Received: M arch 29, 2003, Accepted: M ay 7, 2003)

\section{Introduction}

With the common occurrence of deoxynivalenol (DON) and nivalenol (NIV) in cereals, it is important not only to understand the factors that lead to their occurrence, but also to determine management strategies to minimize their impact and occurrence in food products ${ }^{11}$. Milling studies of wheat naturally contaminated with Fusarium mycotoxins indicated that the mycotoxins were differentially distributed in the kernel, with relatively higher levels in the dockage, outer bran fractions and shorts, and lower levels in the inner flour fractions ${ }^{2,33}$. DON was not decomposed on making Egyptian bread, western style bread or cookies baked from hard wheat flour ${ }^{2,4,5)}$. In contrast, the effect of baking on DON in non-yeast products was reported as variable, ranging from no effect to $69 \%$ reduction ${ }^{6,7)}$. M oreover, during bread baking, DON and NIV were reduced by 49 and $57 \%$ respectively ${ }^{8)}$. Our experience also indicates that considerable reduction of DON and NIV could be achieved by roasting contaminated barley and wheat kernels ${ }^{9}$.

All these investigations suggest that, depending on the conditions in which the treatment is performed, the elimination of trichothecenes from contaminated cereals is possible; however, information on the decomposition products remained in the commodities is insufficient. Therefore, as an attempt to elucidate the characteristics of the heat-induced compounds, decomposition patterns of 
DON and NIV in naturally co-contaminated barley were determined by two different methods; GCMS and ELISA. The results presented here are some basis for the characterization of the compounds produced during heat treatment of DON and NIV.

\section{Materials and Methods}

Chemicals and Mycotoxins Standards Unless otherwise noted, all reagents were purchased from Wako Pure Chemical Industries, Ltd. (Osaka). Organic solvents were of reagent grade and distilled in a glass apparatus before use. The methyl eicosanoate used as internal standard in GC-M S analysis was obtained from Tokyo Kasei Kogyo Co. For the derivatization of DON and NIV to trimethylsilylated (TM S)-ether, a formulation of N-TM S-imidazole, N,O-bis-TM S-acetamide and TM Schloride (3:3:2, v/ v/ v) was used. Each trichothecene standard solution was prepared by dissolving the toxin in ethanol at $1 \mathrm{mg} / \mathrm{ml}$ level and then kept at $4{ }^{\circ} \mathrm{C}$ for further dilution.

For ELISA, ovalbumin (OVA) and 2, 2'-azino-bis [3-ethylbenzothiazoline-6-sulfonic acid] diammonium salt (ABTS powder and buffer) were obtained from Sigma Chemical Co. (St. Louis, M O, USA) and Boehringer $M$ annheim ( $M$ annheim, Germany), respectively. PBS-T ween solution utilized for plate washing consists of $10 \mathrm{mM}$ sodium phosphate buffer (pH 7.4) containing $140 \mathrm{mM} \mathrm{NaCl}$ (PBS) and $0.05 \%(v / v)$ Tween 20.

\section{Heating Treatments}

1) Kernel Samples Barley kernels ( $200 \mathrm{~g}$ ) were introduced into the gas-roaster, preheated for about 12 min up to $150,170,180$ or $220^{\circ} \mathrm{C}$, and roasted for $5,15,30,45$ or $60 \mathrm{~min}$. The gas level was hand-controlled to maintain a constant temperature during the process. Once the heating time was over, the sample was immediately removed and cooled to room temperature. For mass loss quantification, samples were weighed before and after heating.

2) Standard Mycotoxins An aliquot of each standard solution (equivalent to $100 \mu \mathrm{g}$ ) was evaporated to dryness in a small glass vial $(8 \mathrm{~mm}$ i.d. $\times 50 \mathrm{~mm}, 1 \mathrm{ml}$ ) under air stream and heated in a convection oven at 150,160 or $200{ }^{\circ} \mathrm{C}$ for $5,10,15,20,30,45$ or $60 \mathrm{~min}$. Each treatment was performed in triplicate.

\section{Chemical Analysis}

1) GC-MS analysis Ground samples were extracted with $\mathrm{CH}_{3} \mathrm{CN}-\mathrm{H}_{2} \mathrm{O}$ (3:1) and cleaned up using a Florisil mini-column. The concentration of DON and NIV in all samples was determined as TMSether by GC-MS (Shimadzu GCM S-QP 5000, Shimadzu Co., Kyoto) with selected ion monitoring mode under the following conditions: fused silica capillary column $30 \mathrm{~m} \times 0.25 \mathrm{~mm}$ i.d. (J\&W, CA, USA), carrier gas He at $2 \mathrm{ml} / \mathrm{min}$, column temperature held for $5 \mathrm{~min}$ at $120^{\circ} \mathrm{C}$ and then increased to $280{ }^{\circ} \mathrm{C}$ at $8{ }^{\circ} \mathrm{C} / \mathrm{min}$, injector temperature $280^{\circ} \mathrm{C}$, interface temperature $250{ }^{\circ} \mathrm{C}$, ionizing voltage $70 \mathrm{eV}$, ionizing current $300 \mu \mathrm{A}$, scanning rate $1 \mathrm{scan} / \mathrm{s}$, and sampling rate for selected ion monitoring 5 points/ s. Selected ions were m/ z 422 and 407 for DON, m/ z 379 and 289 for NIV, and m/ z 326 and 283 for methyl eicosanoate (internal standard) ${ }^{10}$. The recoveries and variation coefficients (in parentheses) of barley powder containing $1 \mu \mathrm{g} / \mathrm{g}$ of each toxin were $97 \%(2.6)$ and $98 \%(4.4)$ for DON and NIV, respectively. At $0.5 \mu \mathrm{g} / \mathrm{g}$ the recoveries were $96 \%(2.6)$ and $95 \%(3.8)$, and at $0.2 \mu \mathrm{g} / \mathrm{g}$ they were $91 \%(2.5)$ and $93 \%(6.8)$ for DON and NIV, respectively. 
2) HPLC analysis Unheated and heated standards were analyzed by HPLC with UV detection under the following conditions: Shimadzu SCL-6A system connected to a Shimadzu SPD-M 10A vp diode ar ray detector interfaced to a Shimadzu CBM -10A communications bus module and Shimadzu CLASS-LC10 model FM V-6300 DX 2c computer, column Shim-pack CLC-ODS, $150 \mathrm{~mm} \times 6 \mathrm{~mm}$ i.d. (Shimadzu Co., Kyoto), oven temperature $40{ }^{\circ} \mathrm{C}$, wavelength 220 and $270 \mathrm{~nm}$, mobile phase watermethanol-acetonitrile ( $70: 7: 3, \mathrm{v} / \mathrm{V} / \mathrm{v}$ ) at a flow rate of $1.2 \mathrm{ml} / \mathrm{min}^{11}$ ).

ELISA Analysis ELISA analysis was conducted according to the method reported by Ikeda et al. (The $52^{\text {nd }} M$ eeting of the Japanese Association of M ycotoxicology, Tokyo, January 4, 2002). Ground samples $(5 \mathrm{~g})$ were extracted with methanol - water $(3: 1, \mathrm{v} / \mathrm{v}, 20 \mathrm{ml})$ and stirred regularly for $1.5 \mathrm{hr}$. An aliquot $(2 \mathrm{ml})$ of the filtrate was diluted with methanol $(2 \mathrm{ml})$, cooled in ice for $4 \mathrm{hr}$ and centrifuged ( $1400 \times \mathrm{g}, 15 \mathrm{~min})$. A portion $(160 \mu \mathrm{l})$ of the supernatant was evaporated to dryness and reacted with dried pyridine $(50 \mu \mathrm{l})$ and acetic anhydride $(25 \mu \mathrm{l})$ at $45{ }^{\circ} \mathrm{C}$ for $40 \mathrm{~min}$. The reaction solution was evaporated to dryness under air stream without heating, dissolved in $100 \mu$ ethanol and then diluted with $900 \mu$ PBS-T ween. Under these conditions DON and NIV are partially acetylated to yield 3,15-diacetyI-DON (3,15-DADON) and 3,4,15-triacetyI-N IV (3,4,15-TANIV), respectively.

A 96-well ELISA plate (F96 M axisorp, Nunc-Immuno Plate, Nalge Nunc International Co., Tokyo) was coated with 4,15-diacetyl-N IV-3-0-hemisuccinate-OVA (4,15-D ANIV-3-O- HS-OVA) in $0.1 \mathrm{M} \mathrm{NaHCO}_{3}$ $\mathrm{Na}_{2} \mathrm{CO}_{3}$ buffer $(0.4 \mu \mathrm{g} / \mathrm{ml}, \mathrm{pH} 9.6,100 \mu \mathrm{l} /$ well), and incubated at room temperature for $2 \mathrm{hr}$. The plate was washed 3 times with PBS-T ween, blocked with skim milk ( $1 \mathrm{mg} / \mathrm{ml}$ in PBS, $300 \mu \mathrm{l} /$ well), and kept with this solution until use (stable for 2 months at $4{ }^{\circ} \mathrm{C}$ ). The samples were diluted to a convenient amount (ca. $2 \mathrm{ng}$ toxin/ well) prior to application ( $50 \mu \mathrm{l} /$ well), followed by addition of peroxidaselabeled antibody (KTM -240-POD) in PBS containing $1 \%$ OVA (300 $\mathrm{ng}$ antibody/ ml, $50 \mu \mathrm{l} /$ well) for the simultaneous detection of 3,15-DADON and 3,4,15-TANIV. Then, the plate was incubated at room temperature for $1 \mathrm{hr}$ and washed 6 times ( 3 times twice). An aliquot of ABTS substrate solution ( $1 \mathrm{mg} / \mathrm{ml}$ in ABTS buffer, $50 \mu \mathrm{l} /$ well) was added, incubating at room temperature for $30 \mathrm{~min}$ prior to measurement with an immuno-microplate reader NJ-2300 (Inter M ed Japan, Tokyo) at $414 \mathrm{~nm}$. Each sample was analyzed in triplicate.

\section{Results and Discussion}

During roasting of naturally contaminated barley, DON and NIV were decomposed with the extent of reduction dependent upon temperature and processing time, for which the greatest effect occurred at the highest temperature. Although the final remaining amount of the toxin was different with each temperature, in all cases the reduction pattern determined by GC-M S was the same; rapid at the early stage followed by no change or slight decrease. After partial acetylation, the same naturally contaminated barley samples were analyzed by ELISA. Roasting at above $170{ }^{\circ} \mathrm{C}$ resulted in a clear decrease of total trichothecenes level (3,15-DADON +3,4,15-TANIV) in the samples analyzed by ELISA as shown in Fig. 1A. The reduction pattern was the same as GC-M S, however, at $150{ }^{\circ} \mathrm{C}$ the toxin level increased after 5 and 30 min heating ( 57 and $62 \%$ respectively), in contrast to the GC-M S analysis, for which a slight decomposition was observed as shown in Fig. 1B.

Two different possibilities were proposed to explain the increase in toxin level; firstly, 


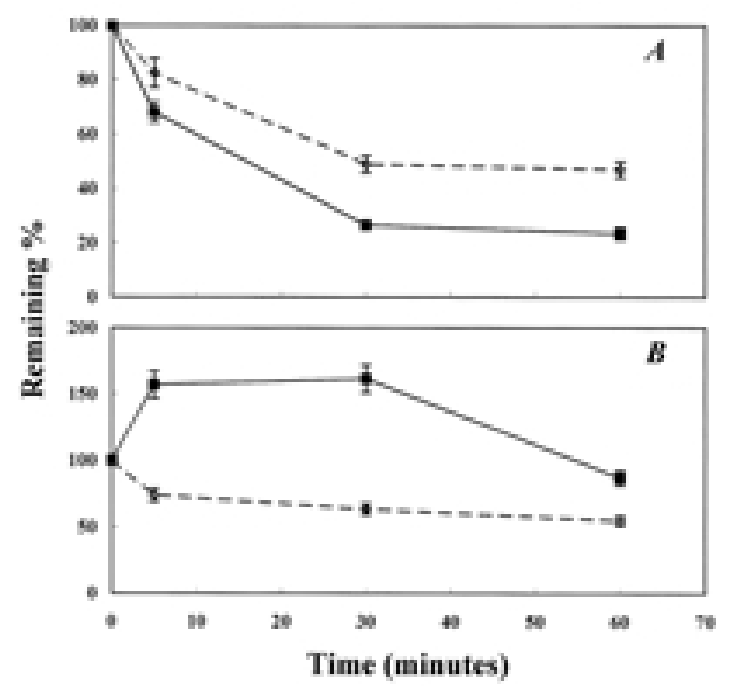

Fig. 1. Effect of roasting at (A) $170{ }^{\circ} \mathrm{C}$ and (B) $150{ }^{\circ} \mathrm{C}$ on total DON and NIV concentration in naturally contaminated barley determined by GC-M S (- - - - - - ) and ELISA (-). Each point represents the mean of three replications.

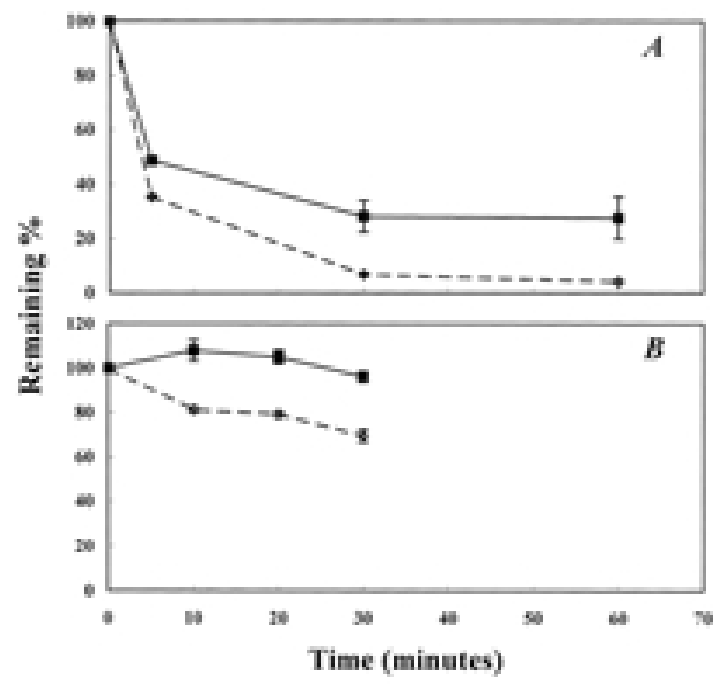

Fig. 2. Effect of heating at (A) $200^{\circ} \mathrm{C}$ and (B) $150{ }^{\circ} \mathrm{C}$ on DON standard determined by GCMS (-----) and ELISA (—). Each point represents the mean of three replications.

compounds derived from DON and NIV during roasting may have stronger cross-reactivity than the parent toxins against the antibody (KTM-240-POD) and secondly, heat-induced products of food components may have some affinity against the antibody. To clarify these possibilities, heat treatment on DON and NIV standards, as to eliminate the matrix effects, was carried out.

In GC-MS analysis, concentration of DON standard was found to be decreased by 21,28 and $93 \%$ 
after heating for $30 \mathrm{~min}$ at 150,160 and $200{ }^{\circ} \mathrm{C}$, respectively. ELISA analysis also showed a clear decrease of DON standard heated at 160 and $200{ }^{\circ} \mathrm{C}$, whereas at $150{ }^{\circ} \mathrm{C}$ an apparent increase of 8 and $5 \%$ occurred after 10 and 20 min heating, respectively, as shown in Fig. 2. The same phenomenon was also observed for NIV standard (data not shown).

Thus, the above mentioned results clearly indicate that heat-treated DON and NIV produce certain heat-induced compounds with stronger cross-reactivity than the parent toxins against the used antibody. If the heating process continues, the parent and the heat-induced compounds were found to be completely decomposed, suggesting that roasting is an effective method to eliminate DON and NIV in co-contaminated cereals such as barley.

The characteristics of the heat-induced compounds with stronger cross-reactivity than the parent toxins against the antibody were of special concern. Taking into account that the antibody KTM -240POD can recognize specifically the partially acetylated derivatives (3,15-DADON and 3,4,15-TANIV), it is suggested that a structural change due to the rearrangement of A-ring in the trichothecenes probably occurred. Greenhalgh et al. ${ }^{12)}$ reported the presence of a DON-related compound in bread made from contaminated flour. This compound (isoDON) has an 8-hydroxy-8-en-7-one moiety with $\lambda_{\max }$ at $277 \mathrm{~nm}$. The $\lambda$ max of DON and NIV $(220 \mathrm{~nm})$ corresponds to the absorption of an $\alpha, \beta$-unsaturated ketone with an a-alkyl substituent; however, if the a or $\beta$ substituent is a hydroxyl group the $\pi \rightarrow \pi{ }^{*}$ absorption shifts above $270 \mathrm{~nm}{ }^{13}$. As expected, in the HPLC analysis of DON standard (retention time $\left[\mathrm{t}_{R}\right] 12.7 \mathrm{~min}$ ) heated at $150{ }^{\circ} \mathrm{C}$ for $20 \mathrm{~min}$ (Fig. 3), a decomposition product was detected at $\mathrm{t}_{R}$ $14.8 \mathrm{~min}$ when monitored at $277 \mathrm{~nm}$. Furthermore, in NIV standard ( $t_{R} 6.7 \mathrm{~min}$ ) heated at the same condition, a product at $t_{R} 8.0$ min was observed (Fig. 4). Fig. 5 shows the UV spectra with the maximum absorbance $(220 \mathrm{~nm})$ of DON and NIV shifted to $277 \mathrm{~nm}$ in the respective decomposition products, suggesting the possible rearrangement of the 7-hydroxy-9-en-8-one moiety in the parent
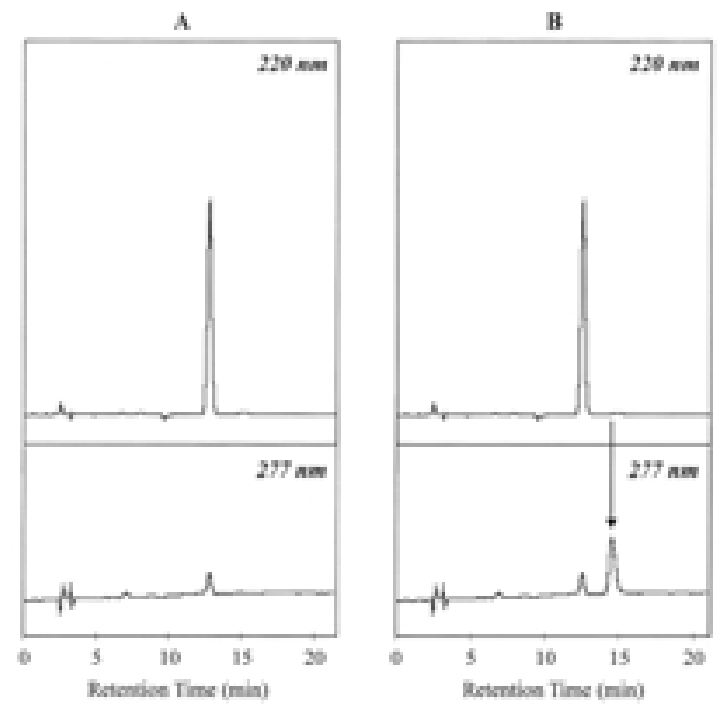

Fig. 3. HPLC chromatogram of (A) DON unheated standard and (B) DON standard heated at $150{ }^{\circ} \mathrm{C}$ for 20 min monitored at 220 and $277 \mathrm{~nm}$. The arrow indicates the decomposition product. 
toxins to an 8-hydroxy-8-en-7-one moiety in the products.

Although the results presented here do not fully explain the toxin augment observed in roasted barley samples because the toxins in naturally contaminated cereals are in a more complex environment, the structural rearrangement that take place with DON in processed cereal samples ${ }^{12)}$ may be also observed for NIV.

Undoubtedly roasting offers a promissory alternative for the reduction of mycotoxins in contaminated cereals. However, when this treatment is conducted at low temperatures, part of this reduction is possibly a structural rearrangement. Bearing in mind that DON and NIV toxicity is
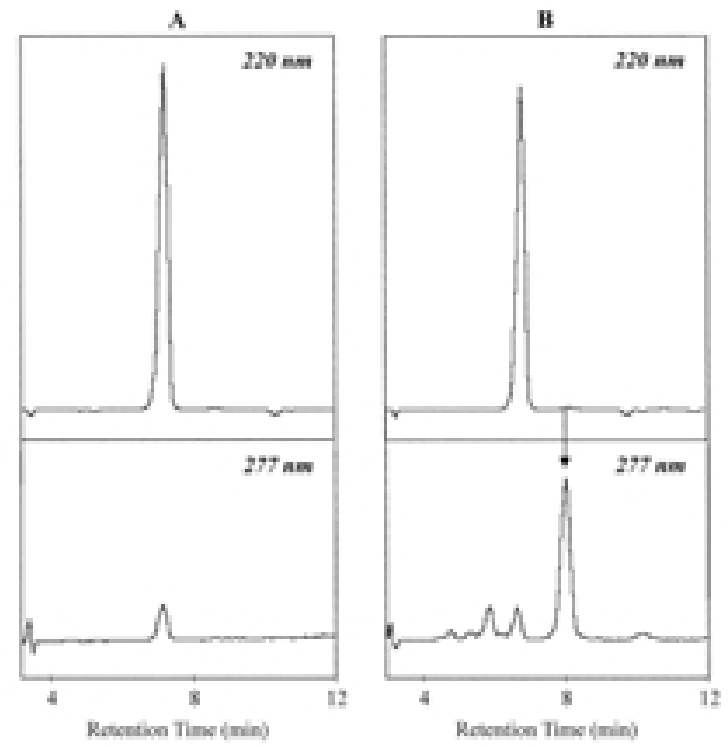

Fig. 4. HPLC chromatogram of (A) NIV unheated standard and (B) NIV standard heated at $150{ }^{\circ} \mathrm{C}$ for $20 \mathrm{~min}$ monitored at 220 and $277 \mathrm{~nm}$. The arrow indicates the decomposition product.

A

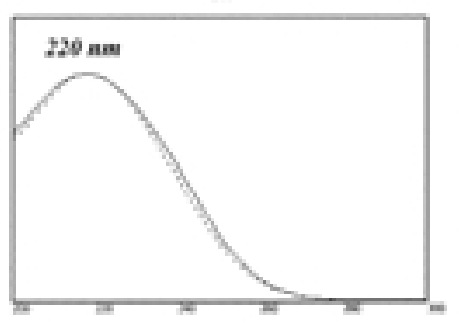

Is

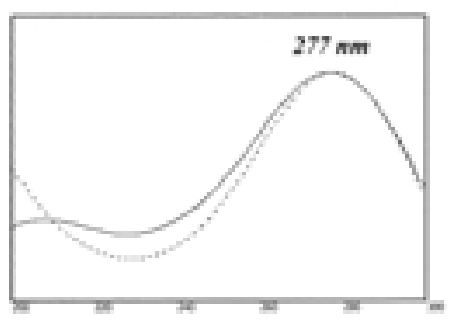

Fig. 5. UV spectra for (A) DON and NIV, and (B) their respective decomposition products. The spectra were obtained with a diode array detector by scanning the peaks in Fig. 3 and 4.

DON and its product

NIV and its product 
mainly determined by the presence of the 12, 13epoxy ring, it can be assumed that under these conditions the toxicity of the mycotoxins or their heat-induced compounds in commodities will not decrease. The final confirmation of the structure of heat-induced compounds, the determination of their cross-reactivity and toxicity will be the subject of a further publication.

\section{References}

1 ) Lauren, D.R., Smith, W.A.: Food Addit. Contam., 18, 1011-1016 (2001)

2 ) Scott, P.M., Kanhere, S.R., Lau P.-Y., Dexter, J.E., Greenhalgh, R.: Cereal Chem., 60, $421-424$ (1983)

3 ) Lee, U.-S., J ang, H.-S., Tanaka, T., O h, Y.J., Cho, C.-M ., Ueno, Y.: J. Agric. Food Chem., 35, 126-129 (1987)

4 ) El-Banna, A.A., Lau, P.-Y., Scott, P.M .: J. Food Prot., 46, 484-486 (1983)

5 ) Scott, P.M., Kanhere, S.R., Dexter, J.E., Brennan, P.W., Trenholm, H.L.: Food Addit. Contam., 1, 313-323 (1984)

6 ) Young, J.C., Fulcher, R.G., Hayhoe, J.H., Scott, P.M ., Dexter, J.E..: J. Agric. Food Chem., 32, 659-664 (1984)

7 ) Abbas, H.K., M irocha, C.J., Pawlosky, R.J., Pusch, D.J.: Appl. Environ. M icrobiol., 50, $482-486$ (1985)

8 ) Kamimura, H., Nishijima, M., Saito, K., Yasuda, K., Ibe, A., Nagayama, T., Ushiyama, H., Naoi, Y.: J. Food Hygien. Soc. Japan, 20, 352-357 (1979)

9 ) Yumbe-Guevara, B.E.: M aster Thesis, Kagawa University (2000)

10) Yoshizawa, T., Jin, Y.-Z.: Food Addit. Contam., 12, 689-694 (1995)

11) Shirai, Y., Ono, Y., Akimoto, K.: Res. Rep. Anim. Feed, 26, 1-9 (2001)

12) Greenhalgh, R., Gilbert, J., King, R.R., Blackwell, B.A., Startin, J.R., Shepherd, M .J.: J . Agric. Food Chem., 32, 1416-1420 (1984)

13) Rao, C.N.R.: Ultraviolet and Visible Spectroscopy, Chemical Applications, (1964), Butterworth \& Co. Ltd., London

焙煎による自然污染大麦中のデオキシニバレノールとニバレノールの減少

ユンベ・ブランカ , 芳澤宅實 : 香川大学農学部 (761-0795 香川県木田郡三木町池戶)

焙煎による自然污染大麦中のデオキシニバレノール (DON) 及びニバレノール (NIV) の分解について， GC-M S またはモノクローナル抗体を用いた ELISA で検討した . DON と NIV が加熱温度と加熱時間に依存 して分解されることが GC-MS で確認された . しかし , 150C で 5 分あるいは 30 分の加熱条件下では, GCMS 分析では僅かな減少にもかかわらず,ELISA では増加することが認められた . この現象は両トキシンの 標準品を $150^{\circ} \mathrm{C} て ゙$ 加熱した際にも確認され，トキシンの加熱生成物がモノクローナル抗体に対して高い交差 反応性を示すことが示唆された 。

キーワード : デオキシニバレノール, ニバレノール, 焙煎, GC-MS, ELISA 